\title{
Impacts of forest changes on hydrology: a case study of large watersheds in the upper reaches of Minjiang River watershed in China
}

\author{
X. Cui ${ }^{1}$, S. Liu ${ }^{1}$, and X. Wei ${ }^{2}$ \\ ${ }^{1}$ Institute of Forest Ecology, Environment and Protection, Chinese Academy of Forestry, Beijing, 100091, China \\ ${ }^{2}$ Earth and Environmental Science, University of British Columbia (Okanagan campus), Kelowna, BC, V1V 1V7, Canada
}

Correspondence to: X. Wei (adam.wei@ubc.ca)

Received: 6 May 2012 - Published in Hydrol. Earth Syst. Sci. Discuss.: 25 May 2012

Revised: 13 October 2012 - Accepted: 16 October 2012 - Published: 20 November 2012

\begin{abstract}
Quantifying the effects of forest changes on hydrology in large watersheds is important for designing forest or land management and adaptation strategies for watershed ecosystem sustainability. Minjiang River watershed, located in the upper reach of the Yangtze River basin, plays a strategic role in the environmental protection and economic and social well-being for both the watershed and the entire Yangtze River basin. The watershed lies in the transition zone from Sichuan Basin to Qinghai-Tibet Plateau with a size of $24000 \mathrm{~km}^{2}$. Due to its strategic significance, severe historic deforestation and high sensitivity to climate change, the watershed has long been recognized as one of the highest priority watersheds in China for scientific research and resource management. The purpose of this review paper is to provide a state-of-the-art summary on what we have learned from several recently completed research programs (one of them known as "973 of the China National Major Fundamental Science" from 2002 to 2008). This summary paper focused on how land cover or forest change affected hydrology at both forest stand and watershed scales in this large watershed. Inclusion of two different spatial scales is useful, because the results from a small spatial scale (e.g. forest stand level) can help interpret the findings on a large spatial scale. Our review suggests that historic forest harvesting or land cover change has caused significant water yield increase due to reduction of forest canopy interception and evapotranspiration caused by removal of forest vegetation on both spatial scales. The impact magnitude caused by forest harvesting indicates that the hydrological effects of forest or land cover changes can be as important as those caused by
\end{abstract}

climate change, while the opposite impact directions suggest their offsetting effects on water yield in the Minjiang River watershed. In addition, different types of forests have different magnitudes of evapotranspiration (ET), with the lowest in old-growth natural coniferous forests (Abies faxoniana Rehd. et Wils.) and the highest in coniferous plantations (e.g. Picea asperata Mast.) among major forest types in the study watershed. This suggests that selection of different types of forests can have an important role in ET and consequently water yield. Our synthesis indicates that future reforestation and climate change would likely produce the hydrological effects in the same direction and thus place double the pressure on water resource as both key drivers may lead to water yield reduction. The findings can support designing management strategies for protection of watershed ecological functions in the context of future land cover and climate changes.

\section{Introduction}

It is commonly accepted that in large, forest-dominated watersheds (greater than $1000 \mathrm{~km}^{2}$ ) forest change or land cover change and climatic variability are two main drivers for hydrological changes at watershed scales. Consequently, understanding their individual effects on hydrological changes requires quantitative separation of the interactive influence on watershed hydrology between land cover change and climatic variability. In small watersheds (less than $100 \mathrm{~km}^{2}$ ), a paired-watershed experimental approach (involving a control 
watershed and a comparable but treated watershed) is commonly used to remove the climatic influence so that the effects of land cover or forest change (e.g. harvesting or plantation) on hydrology can be quantified. However, such an experimental approach is not suitable for large watersheds simply because of the difficulty in locating a comparable control watershed for an impacted watershed. In order to overcome this methodological challenge, various approaches have been explored, including hydrological modeling (Tuteja et al., 2007), statistical analysis (Wei and Zhang, 2010; Zhao et al., 2010), sensitivity tests (Milly and Dunne, 2002) and trend analysis (Wilcox and Huang, 2010).

Many studies have demonstrated that forest changes can significantly affect streamflow by altering its pattern, magnitude, frequency and quality (Bethlahmy, 1974; Cheng, 1989; Scott and Lesch, 1997; Moore and Wondzell, 2005; Doerr and Shakesby, 2006). However, the majority of these conclusions have been based on small watersheds with much less attention given to the large watersheds (Wilk et al., 2001; Costa et al., 2003; Sun et al., 2005; Tuteja et al., 2007; Lin and Wei, 2008). In the past few decades, large watershed studies have been receiving growing attention because many environmental issues have cumulative effects and operate on large spatial scales. Watershed resource managers are eagerly seeking scientific information on large watersheds to support resource management for protection of water resources and mitigation of floods and droughts. This is particularly evident when climate change and anthropogenic activities are dramatically altering watershed processes on large spatial scales.

Research on evaluating cumulative hydrological impacts of forest changes or land cover change and climatic variability in large watershed systems is challenging and limited, mainly because of insufficient data and complexity. Moreover, research results on forest disturbance and hydrological effects in large watersheds are less consistent when compared with the small watershed studies. For example, studies have demonstrated that hydrological impacts of deforestation in large watersheds were insignificant (Wilk et al., 2001; Buttle and Metcalfe, 2000; Robinson et al., 2003; Thanapakpawin et al., 2007). In contrast, significant hydrological responses to deforestation have been identified in many other large watershed studies (Eschner and Satterlund, 1966; Ring and Fisher, 1985; Matheussen et al., 2000; Huff et al., 2000; VanShaar, 2002; Siriwardena et al., 2006; Li, 2007). Those inconsistent results may be due to significant complexities in large watersheds as well as different research methods applied. They also demonstrate that the forest-water relationship in large watersheds is likely watershed specific, and thus more case studies need to be investigated in detail.

Minjiang River is the largest tributary of Upper Yangtze River in terms of its water yield (approximately $8.9 \%$ ). The watershed provides critical water supply to the downstream Chengdu and nearby regions for agricultural and industrial development. However, due to historic deforestation, over-grazing and increasing population, there are various environmental problems such as floods, soil erosion, water pollution and seasonal shortage of water supply. In addition, the watershed is sensitive to changes in climate due to its high elevations. Water resources in the Tibetan Plateau decreased with shrinking glaciers and permanent snowpack (Shi and Li, 1994; Kang, 2005). Thus, because of its significance, growing pressures and high sensitivity to climate change, Minjiang River watershed has always been a high-priority in the Yangtze River basin and western regional development of China.

The research of the Minjiang River watershed can be traced back to the 1960s, which was one of the frontiers in Chinese forest hydrological research. Recently, the Ministry of Science and Technology funded an integrated watershedwide research program $(\$ 25$ million Chinese RMB, about $\$ 3.5$ million USD) to study various watershed processes in the Minjiang River watershed (2002-2008) to improve science and management in large watersheds. The program was led by the Chinese Academy of Forestry (Shirong Liu) with involvement from more than 20 research institutes across China.

The purpose of this summary paper is (1) to provide the research findings on ecohydrological processes at the forest stand level; (2) to present the results on the effects of forest change or land cover change and climatic variability on hydrology at the large watershed scale; and (3) to integrate all results at both spatial scales to discuss management strategies for long-term water and watershed sustainability. Although our review mainly focuses on the large watershed scale, inclusion of the results from the small forest stand scale will help the interpretation of the results obtained at large spatial scales.

\section{Characteristics of Minjiang River watershed}

Minjiang River watershed is located in the upper reach of Yangtze River basin, with an area of $24000 \mathrm{~km}^{2}$ (Fig. 1). The watershed lies in the transition zone from Sichuan Basin to Qinghai-Tibet Plateau, covering elevations ranging from about 500 to $5500 \mathrm{~m}$, with the high elevations covered by glaciers and permanent snow. The eco-environment in Minjiang River watershed is typically vulnerable due to its high elevation, steep topography, high hydraulic gradient and abundant rainfall. The main watercourse of the upper watershed is $340 \mathrm{~km}$ in length, and the elevation differences are up to $4000 \mathrm{~m}$.

The climate in Minjiang watershed is characterized by typical alpine climate with high spatial and vertical variations (Fig. 2), with one exception in the elevation band of 1800 $2300 \mathrm{~m}$ where the arid valley has a subtropical climate. There are also alpine frigid zones and tierra helada above the alpine tree line. Average annual temperature decreases from southeast to northwest. The maximum annual temperature of the whole watershed is $15^{\circ}$ and the minimum is less than $4^{\circ}$. 


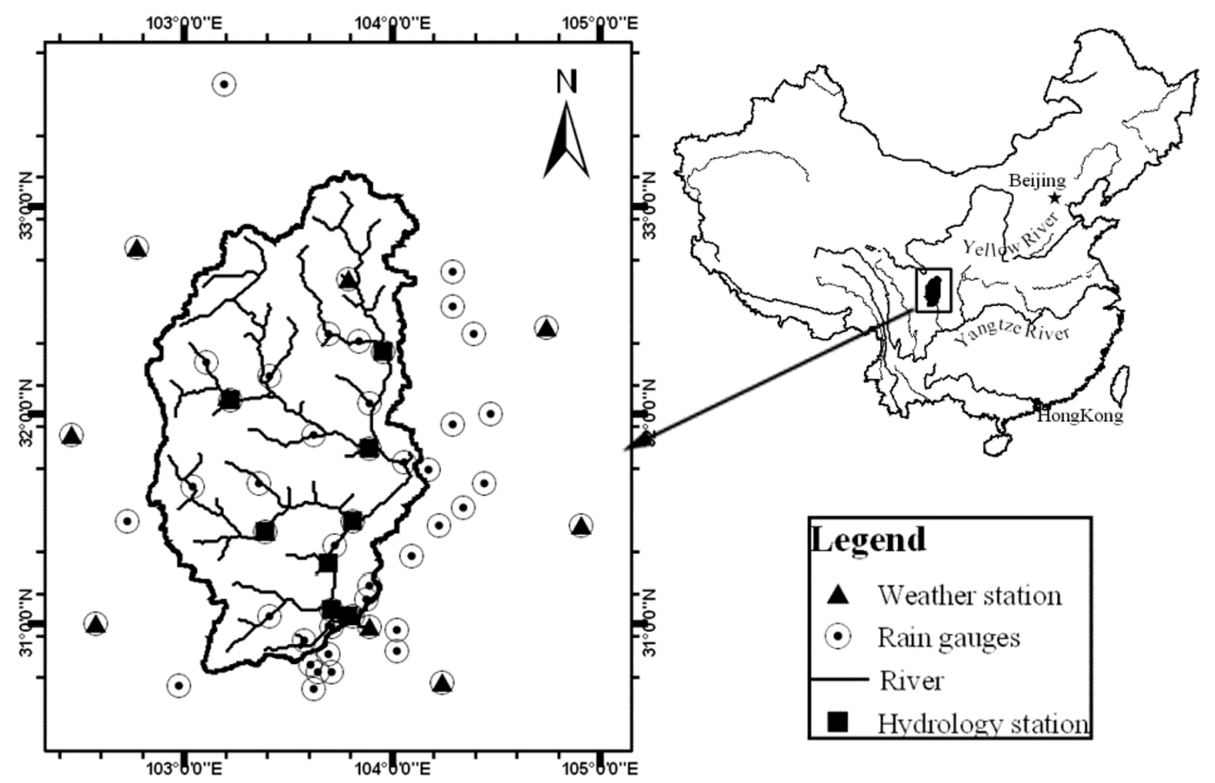

Fig. 1. Location of the Minjiang River watershed and distribution of climate and hydrometric stations (cited from Sun et al., 2008).
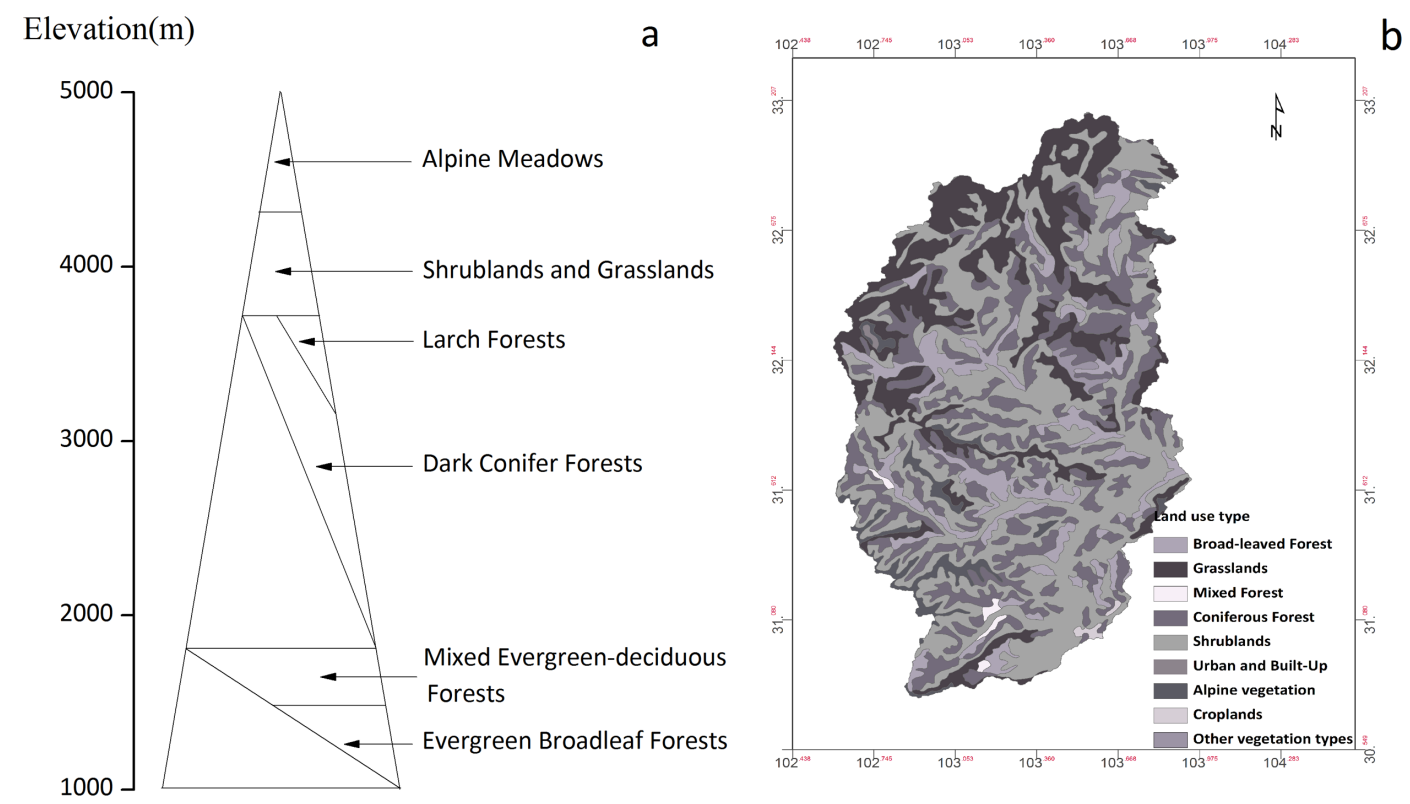

Fig. 2. Vertical distribution pattern of vegetation (a), and land use and land cover distribution (b) in the Minjiang River watershed.

The climate is mainly affected by westerly circulation, southwest and southeast Monsoons, which lead to a rainy season from May to October covering $75-90 \%$ of the total annual precipitation.

The major type of soil is mountainous, brown, coniferous forest soil originating from limestone, phyllite and basalt. Various soil types are distributed vertically along elevations. Yellow brown soil normally distributes in the low elevation areas or areas where the precipitation amount is high. Mountainous cinnamonic soil is mainly distributed in the elevations of 1500-2000 m, while leaching cinnamonic soil and carbonate cinnamonic soil can be found in the elevations of $2000-2800 \mathrm{~m}$. Mountainous brown soil is distributed in the elevations of 3000-3700 m, and subalpine meadow soil, alpine meadow soil and alpine frost desert soil can be found above $3800 \mathrm{~m}$.

The Minjiang River watershed is located in the transition area from southeast humid forest region to northwest arid grassland with a distinct vertical pattern (Fig. 2). The watershed consists of evergreen broad-leaved forest, coniferous 
forest, mixed coniferous and broad-leaved forest, shrublands, grasslands, alpine meadows, croplands, and other land cover types (Fig. 2). The dominant vegetation types are meadows, coniferous forests, and shrublands. In total, they occupy $90 \%$ of the land cover and their proportions total 36.6, 30.7, and $22.8 \%$, respectively (Y. Zhang et al., 2008). The dominant tree species is Abies faxoniana Rehd. et Wils.

\section{Land use or forest and climate changes}

The upper Minjiang valley was historically covered by dense natural forests and vast grasslands and meadows. After the foundation of the People's Republic of China (1949), forest harvest became the primary practice in the upper Minjiang River watershed, with massive timber harvest mainly occurring from the 1950s to the 1970s. With the population growth and the increasing demand for wood supply, many forested lands were converted to farmlands. The forest stock volume decreased $3.0 \times 10^{9} 1$ per year and the forest coverage reduced by approximately $0.47 \%$ per year from 1949 to 1980 (Fan, 2002). As a result, the forest coverage reduced to $18.8 \%$ and the forest stock volume was only $47 \%$ of the original volume in the watershed. With reforestation, the forest coverage then rose to $27 \%$ in 1990 . Following the severe flood of the Yangtze River in 1998, the Chinese central government decided to ban any logging in upper Yangtze River and launched a series of reforestation and forest protection programs. Implementation of those reforestation programs dramatically increased forest coverage to $34 \%$ in 2006 in the Minjiang River watershed. It is expected that this coverage rate will continue to grow in the study watershed as China sets an ambitious goal of $28 \%$ forest coverage by 2050 in the whole of China (J. Liu et al., 2008).

Zhou et al. (2008) documented the changes of major vegetation types in the upper Minjiang River watershed during the recovery period based on data from 625 sampled plots. They found that $21 \%$ of the shrubland had been changed to closed forests, open forests and plantation forests, while $17 \%$ of the agricultural land had been converted to forests, shrubs and grasslands. In addition, $13 \%$ of the grassland had been changed to shrubland. For the major tributary (Zagunao watershed) of the upper Mingjiang River watershed, Zhou et al. (2008) showed that old-growth coniferous forests were dominant prior to 1954 , and then were severely logged between 1954 and 1978, especially between 1954 and 1965 with more than $1 \%$ of total watershed area per year logged (Zhang et al., 2005, 2011). After 1965, harvesting activities decreased dramatically, with an average annual clear-cut rate of $0.2 \%$ from 1966 to 1978 and $0.1 \%$ from 1979 to 1996 . Up to 1996 , about $15.5 \%$ of the watershed (about $50 \%$ of forest land) was harvested.

Minjiang River watershed is sensitive to climate change. The Qinghai-Tibet Plateau has become warmer in the past $30 \mathrm{yr}$ at a rate of $0.19-0.25^{\circ} / 10 \mathrm{yr}$ in the subalpine forest zone, which lies at elevations between 2600 and $3600 \mathrm{~m}$ (Liu and Hou, 1998; Tan et al., 2000). Annual precipitation has decreased by $23.5-28.6 \mathrm{~mm}$ over a period of $10 \mathrm{yr}$ in the past $20 \mathrm{yr}$ (Lú and Lú, 2002). The atmospheric temperature in Qinghai-Tibet Plateau is expected to increase $2-3.6^{\circ}$ by 2100 , according to the results of a General Circulation Model (GCM) (Johns et al., 1997).

\section{Impacts of forest changes on water at a forest stand level}

Information on hydrological processes in a forest stand level provides important mechanisms for understanding ecohydrological processes in large spatial scales. The stand-level forest hydrological processes summarized here include forest canopy and litterfall interception, water movement and water use strategy, evapotranspiration and water production.

Forest canopy interception is the water intercepted by forest canopy during rainfall or snowfall events. The intercepted water goes back into the atmosphere through the evaporation process. The forest canopy interaction reduces kinetic energy of raindrops and thus protects soils from soil erosion. However, it also represents a portion of water lost from a water production perspective. The percentages of forest canopy interception vary with leaf area index, precipitation characteristics and types of forests. According to Hörmann et al. (1996), the canopy interception ratios of temperate broadleaved and coniferous forests are $11-36 \%$ and $9-48 \%$, respectively. In the Minjiang River watershed, the canopy interception ratios ranged from about 20 to $50 \%$, depending on types of forests studied (Table 1). Those studies are consistent with earlier research on Abies faxoniana in Western Sichuan and elsewhere in China where 20-70\% interception ratios were reported (Liu et al., 2001; Song, 2007). Table 1 also showed that the interception ratios were varied with the same vegetation type (Lú et al., 2007; Ma, 1987). A close examination on the rainfall events indicated that the medium rainfall intensities were dominant in the study by Ma (1987), while heavy ones were dominant for the study by Lú et al. (2007), suggesting that rainfall intensities are an important factor influencing canopy interception ratios (Fu et al., 2010).

Like forest canopy, litter layer on soil surface plays a similar role in hydrological cycling. In evaluating the role of litterfall in water interception, water-holding capacity of litterfall is commonly used. The water-holding capacity of litterfall is mainly affected by forest types, amount of litterfall, and decomposition conditions (Richard, 1980; Ma, 1993). The major forest type of the study area is Abies faxoniana forest. It has a much greater maximum soil water-holding capacity, maximum litter water-holding capacity and maximum moss layer water-holding capacity than other vegetation types, such as the second growth forests and plantation forests in the study watershed (Liu et al., 2001). Zhang et 
Table 1. Canopy interception of different forest types in the Minjiang River watershed.

\begin{tabular}{|c|c|c|c|c|c|}
\hline Forest types & $\begin{array}{l}\text { Study } \\
\text { area }\end{array}$ & $\begin{array}{l}\text { Altitude } \\
\text { (m a.s.1.) }\end{array}$ & $\begin{array}{l}\text { Forest } \\
\text { canopy } \\
\text { coverage } \%\end{array}$ & $\begin{array}{l}\text { Canopy } \\
\text { interception } \\
\text { ratio } \%\end{array}$ & Reference \\
\hline $\begin{array}{l}\text { Mixed plantation of } \\
\text { Pinus tabulaeformis } \\
\text { Carr. with } \\
\text { Pinus armandii Franch }\end{array}$ & $\begin{array}{l}\text { Dagou } \\
\text { River } \\
\text { valley }\end{array}$ & 1984 & 90 & 50.0 & Chang et al. (2006) \\
\hline $\begin{array}{l}\text { Subalpine forest: } \\
\text { Quercus aquifolioides } \\
\text { Rehd. et Wils. }\end{array}$ & $\begin{array}{l}\text { Wolong } \\
\text { Nature } \\
\text { Reserve }\end{array}$ & 2805 & 80 & 16.8 & He et al. (2010) \\
\hline $\begin{array}{l}\text { Natural Alpine } \\
\text { faxoniana forests } \\
\text { Abies }\end{array}$ & $\begin{array}{l}\text { Wolong } \\
\text { Nature } \\
\text { Reserve }\end{array}$ & $2780-4080$ & $20-70$ & 48.2 & Lủ et al. (2007) \\
\hline $\begin{array}{l}\text { Natural Abies } \\
\text { faxoniana forests }\end{array}$ & Miyaluo & $1400-3000$ & $30-70$ & $19.8-27.4$ & Ma (1987) \\
\hline
\end{tabular}

al. (2009) compared the water-holding capacities of different vegetation types using both field investigation and laboratory experiments in the subalpine region of Western Sichuan, and found that the maximum water-holding capacities at the litter layer and soil layer of $0-40 \mathrm{~cm}$ were significantly higher in natural forests than those in plantation forests. Those results clearly indicated that natural forests have a higher water-holding capacity in litter layers than plantation forests, mainly because the former have more litterfall accumulation than the latter do in the study area. This result is also consistent with those from Yu et al. (2003) and Shi et al. (2004), which showed higher soil infiltration rates found in natural dark coniferous forests in upper reaches of Yangtze River Basin.

Studying water movement in soil profile using isotope composition $(\delta \mathrm{D})$ can be useful for determining sources of water and flow-paths in a watershed. Using the isotopic method, $\mathrm{Xu}$ et al. (2011a) analyzed the responses of $\delta \mathrm{D}$ to different rainfall intensities in different soil layers (litter, humus, illuvial, mineral soil and shallow aquifer) in a subalpine, dark coniferous forest in the Wolong Natural Nature Reserve of the study watershed. They found that different soil layers had different responses (change rates and lengths of residence time) to rainfall intensities and subsequent evapotranspiration, with quick responses in top layers and slow responses in deep layers. Their results clearly showed that light rainfall $(5-15 \mathrm{~mm})$ events only temporally altered the shape of $\delta \mathrm{D}$ profile curve of soil water, and their impacts on the upper soil depth were quickly depleted through evaporation and plant uptake. In contrast, heavy rainfall events (about $30 \mathrm{~mm}$ ) greatly affected the shape of $\delta \mathrm{D}$ profile curve of soil water in all layers (Xu et al., 2011a). Surprisingly, groundwater in shallow aquifers was not significantly altered at this heavy rainfall intensity.
In a separate study, $\mathrm{Xu}$ et al. (2011b) used the isotopic method to examine water use strategies of three different plant species in the same forest community described earlier. In this study, Xu et al. (2011b) focused on the resultant patterns of soil water redistribution to examine the processes of soil water redistribution. The results showed that the patterns of water use by three species (Abies faxoniana, Betula utilis D. Don. and Bashania fangiana (A. Camus Keng f. et Wen)) displayed strong agreement with their fine root distributions in the soil profile. The overstory species of Abies faxoniana showed a balanced reliance on both groundwater and rainfall, and displayed little difference in its water use strategy between the wet season (August) and the dry season (March). In contrast, the midstory species of Betula utilis and the understory species of Bashania fangiana were highly responsive to rainfall, especially in the wet season. Those contrasting results suggest that the complementary water use strategies and the lack of dependency on rainwater by the foundation species of the subalpine coniferous forest ecosystem should act together to promote species' co-existence and maintain community resiliency under potentially increasing water stress caused by climate change.

Using water isotopic approach, Liu et al. (2006) investigated the effects of vegetation patterns on yields of surface and subsurface water in the Heishui Alpine Valley, one of the major watersheds in the upper Minjiang River. Their study found that reduction in the coverage of total vegetation, forest and subalpine coniferous forests could cause increases in surface and subsurface water yields, while the water yield increased with the increasing alpine shrub and meadow cover. Those relationships were shown at both the low and high altitudes, suggesting that total vegetation cover or land cover configuration plays the most important role in determining water yield at this large watershed scale, while the coniferous 
forest cover would affect the water yield on a relatively small scale.

At a landscape level, different ecosystems or landscape components are ecologically and physically connected by ecohydrological processes (e.g., evaporation and transpiration, evaporation-related rainfall, soil water movement) among different ecosystems (e.g. grasslands, meadows, shrublands, forests). Cui et al. (2009) studied the hydrological connections between subalpine forests and alpine meadows using isotopic analysis, and found that rain and fog in the alpine meadows had high deuterium excess, $35 \%$ and $38 \%$ respectively as compared to $10 \%$ of precipitation brought by monsoons at lower elevations. These high values suggested that a large part of rainfall at the alpine meadows derived from secondarily evaporated water and that fog derived from the evaporated water produced shortly after rainfall events. However, averaged evaporation rates calculated by an isotopic mass balance model of soil water was only $0.26 \mathrm{~mm} \mathrm{day}^{-1}$, about $3.6 \%$ of the rainfall and $7.57 \%$ of the average deuterium excess value of rain. The contribution from evaporated water to precipitation in the alpine meadows therefore had to be mainly from subalpine vegetation in the region. Those ecohydrological relations between subalpine and alpine ecosystems can partly explain the high water yield of the alpine meadows and should be considered for regional resource management.

Evapotranspiration is an important component of water budget in a forested watershed. Y. Zhang et al. (2008) studied the evapotranspiration in the Minjiang River watershed and found that the forests had a higher ET than crops and shrubs. This result suggests that conversion of crops or shrubs to forests will cause water reduction and vice verse. Forests in the Minjiang River watershed were massively cut between the 1950s and 1980s. After 1999, various reforestation programs, including returning some croplands to forests, were implemented into the study watershed and elsewhere in China. Successful implementation of those reforestation and protection programs will lead to the significant conversion of crop or shrub lands to forest lands, and consequently will cause water reduction. This result is consistent with the studies from G. Sun et al. $(2005,2008)$.

There are large variations in ET and consequently water production among different types of forests. Zhang et al. (2011) compared ET among different major types of forests in the Minjiang River watershed and found that ET in old-growth natural coniferous forests (Abies) was the lowest, followed by shrubs, broad-leaved forests, mixed coniferous and broad-leaved forests and coniferous plantations (e.g. Spruce) (Fig. 3). The lowest ET in old natural coniferous forests indicates that the old-growth coniferous forests have the highest water production potentials, and thus the harvesting of this type of forest can cause initial water yield increase due to removal of all vegetation, followed by longterm water yield decrease as a result of succession and regrowth of other types of forests. The highest ET in the

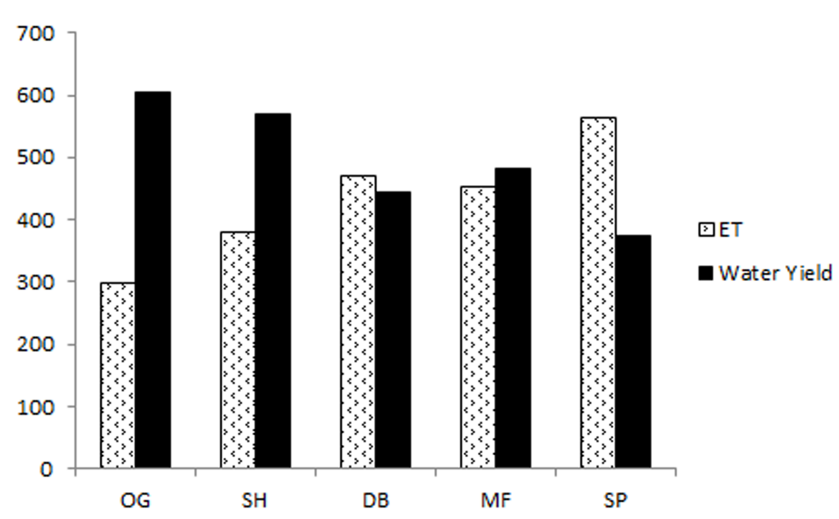

Fig. 3. Annual ET and annual water yield of main forest types in Miyaluo, upper reach of the Minjiang River watershed in 2000 (OG: old-growth natural coniferous forests - Abies; SH: shrub; DB: deciduous broad-leaved forest; mixed broad-leaved with coniferous forests; and SP: spruce plantation forests) (cited from Zhang et al., 2011 with modification).

coniferous plantation highlights that coniferous plantations could greatly cause water reduction in the study watershed. In addition, monoculture coniferous plantations may cause some ecological problems, such as decline in biodiversity, simplified forest structures and habitat, and decline of soil quality. Thus, from an ecological perspective, more mixed forests or broad-leaved forests should be encouraged in the study region.

\section{Effects of forest change on hydrology at watershed scale}

Quantifying the effects of land cover or forest changes on hydrology in large watersheds require explicit consideration or removal of the effects of climate change. Because of the difficulty in applying the paired-watersheds experimental approach to large watersheds, researchers normally use the isotopic method, statistics, modeling and remote sensing techniques to assess the effects of forest changes on hydrology. While these different methods have their own strengths and weaknesses, their applications are largely dependant on the study objectives and availability of high quality data.

Watershed-scale ET provides critical information for understanding water budget and water production at watershed scales. It is closely related to climate (energy and water availability) and vegetation, and its magnitude in a forest watershed is generally greater than that in a bare or nonforested watershed (Liu et al., 1996; Zhou and Yan, 2000). Liu et al. (2006) analyzed basin-wide ET of the upper Minjiang Valley using different methods, including Thornthwaite and SEBAL model, and found that the spatial-temporal patterns of ET were complex. In this study, the daily ET of the non-growth season was estimated to be about $1 \mathrm{~mm}$ day $^{-1}$, which was much lower than that in the growth season 
$\left(2-3 \mathrm{~mm} \mathrm{day}^{-1}\right)$. P. Sun et al. (2008) detected a positive correlation between ET and remote sensing-based Normalized Difference Vegetation Index (NDVI, an index showing vegetation activity) in the Minjiang River watershed. Their study also showed that vegetation activity of alpine vegetation increased significantly due to the climate warming, but no significant response was found in a lower altitude. They further suggested that temperature played a more important role than precipitation in NDVI change in the alpine area, as it increased vegetation activity and associated evaporative water loss. However, water availability may play a more important role than temperature in regulating vegetation change in lower elevation areas according to the study by P. Sun et al. (2008). Thus, they concluded that high mountain vegetation types were the most vulnerable from climate change impacts.

Change in ET could lead to important alterations in streamflow. According to the study from P. Sun et al. (2008), a significantly negative relationship between river flows and NDVI was detected in the growing seasons due to increasing temperatures and vegetation activity, and resultant increasing ET. In addition, P. Sun et al. (2008) found that annual watershed ET increases significantly due to forest composition and structure shifts from degraded forest stands to fast growing shrubs and grasses. Based on those findings, P. Sun et al. (2008) predicted that increasing vegetation cover will likely decrease river flow in this large watershed. In a separate research, Liu et al. (2006) applied both isotope and remote sensing techniques to develop the relationship between forest types and streamflow in seven sub-watersheds of the Minjiang River watershed. They found that reduction in the covers of total vegetation, mixed forests and subalpine coniferous forests could cause an increase in surface and subsurface water yields, while the water yield increased with the alpine shrub and meadow covers. Clearly, both abovementioned studies (albeit different approaches) suggest that land cover change can cause significant hydrological alteration at the watershed scales.

Using both water balance and combination of remote sensing data with an improved Thornthwaite model, L. Zhang et al. (2008) estimated both ET and PET for 4 meso-scale watersheds in the Minjiang River watershed. Their results show that both ET and PET for three studied meso-scale watersheds are relatively low $(39.5-43.8 \%$ and $28.2-47.7 \%$, respectively). Those results are consistent with several previous studies on small watersheds in the Minjiang valley (Chen and Ren, 1990; Ma, 1987; Yang et al., 2004). The relatively low ET may be due to dominance of mature or old-growth natural coniferous forests, as the latter have the lowest ET (see Fig. 3) as described earlier (at the forest stand scale). The low ET across various spatial scales in the Minjiang valley may also be related to the foggy and moist climate in the high-elevation topography of the unique, deeply-cut valley environment (Liu et al., 2001). The relative low ET and thus high water production in the old or mature natural coniferous forests are unique in ecohydrological studies.

The glaciers and permanent snow distributed at the top of the mountains of the watershed are an important source of water resource in the Minjiang valley (Zhang et al., 2002). Using data on $\delta \mathrm{D}$ and $\delta^{18} \mathrm{O}$ sampled over a river network across a large spatial scale in Heishui watershed, a major tributary to the study watershed, Y. Liu et al. (2008a,b) examined the runoff generation, dynamics and hydrograph separation. They found that the contribution of glaciers and snow meltwater to baseflow was dominant, ranging from 63.8 to $92.6 \%$, while rain contributions varied from 7.4 to $36.2 \%$ in the wet season (from May to June). In contrast, the study in Tongtian River, Upper Yangtze River, showed that the contribution of glacier to the total runoff was only $9.2 \%$ (Yang, 1990). These contrasting results suggested large variations in the role of snow and glacier meltwater in baseflow in spite of its significance in water supply. These studies have important implications for future water resource availability as climate change continues and glaciers and permanent snow cover may be diminished under global warming.

$\mathrm{Xu}$ et al. (2008) analyzed the spatial-temporal variations of runoff during 1961-2000 in the Upper Yangtze River using a distributed hydrological model, and found that there were significantly decreasing trends for both precipitation and discharge in the autumn, but increasing trends in the summer. Because summer is the wet season and autumn is the dry season in the upper reaches of Yangtze River Basin, the increasing trends in the summers and decreasing trends in the autumn suggest both increased flood and drought risks. Zhang et al. (2012) conducted a retrospective study to quantify the relative contribution of forest harvesting and climatic variability to hydrology based on the long-term historic data (1953-1996) on climate, streamflow and forest change history in Zagunao sub-watershed, situated in the upper reach of the Minjiang River watershed. The method they employed includes the combination of time series analysis and double-mass curves (Wei and Zhang, 2010). The research showed that the average annual mean flow was significantly increased by forest harvesting, and the increased magnitude attributed to forest harvesting was $38 \mathrm{~mm} \mathrm{yr}^{-1}$, while the annual mean flow variation attributed to climatic variability was $-38.3 \mathrm{~mm} \mathrm{yr}^{-1}$. Both positive and negative values suggested an offsetting effect between forest harvesting and climatic variability. The similar change magnitudes clearly demonstrated that the effects of forest harvesting on hydrology are as important as those from climatic variability. The results from Zhang et al. (2012) also disclosed that the positive effect of forest harvesting on streamflow decreased with forest recovery and eventually diminished about $20 \mathrm{yr}$ following an intensive harvesting period.

Using a modeling approach for simulating the effects of land cover change and climate variability on hydrology in Suomo basin (a large tributary of upper Yangtze River basin), Chen et al. (2005) showed that $63.9 \%$ of annual streamflow 
change was caused by climate variability and $20.8 \%$ by land cover changes, and the other $15.3 \%$ was system error. Cheng (1999) analyzed the runoff change in the process of afforestation and showed that both the low flow and regional water conservation index of river runoff coefficient increased as the forest coverage enlarged from 13 to $21 \%$ in Upper Yangtze Basin. Those two studies further demonstrated that forest changes can greatly alter hydrology in the study watershed.

\section{Implications for management and adaptation strategies}

The results from both the forest stand level and watershed scale clearly showed that forest change or land cover change plays an important role in regulating water resource. Forest harvesting can significantly increase annual streamflow, while reforestation or conversion from croplands will do the opposite in the study watershed. This conclusion is consistent with the wide-held "trade-off" relationship between forest and water summarized by Jackson et al. (2005), which means more trees equal less water, and less trees equal more water. This result should have an important implication for forest and water management as China has been implementing several large-scale reforestation programs since the mid 1990s. These programs include the Natural Forest Protection Program, the Sloping Cropland Conversion Program, the Desertification Combating Program, the Key Shelterbelt Systems Construction Program, and the Wildlife Conservation \& Nature Reserve Construction Program. It is expected that successful implementation of those programs will significantly increase forest coverage, especially coniferous plantation areas in the study watershed, and consequently lead to less annual streamflow in the future.

Our review at both forest stand and watershed scales found that different forest types have different ET estimates and thus water yields. ET in old-growth natural coniferous forests (Abies) was the lowest, while ET in coniferous plantations (e.g. spruce) was the highest at the forest stand scale (Fig. 3). The lowest ET in old natural coniferous forests indicates that the old-growth coniferous forests have the highest water production potentials. The highest ET in the coniferous plantations highlights that coniferous plantations can greatly cause water reduction in the study watershed. At the watershed scale, forest dominated sub-watersheds have higher ET than those dominated by shrub or grasses or meadows, and consequently any conversion from forests to shrubs or grasses would lead to water increase at the watershed scale. Therefore, selection of different forest types has an important role in affecting water yields.

It would be useful to compare the key differences in the forest-water relationship between the Upper Yangtze River and Yellow River basins and their management implications of those differences as both basins have dramatic contrasts in climate. According to ET, Yangtze River basin is commonly viewed as an energy-limited ecosystem, while Yellow River is a typical water-limited region in China. For example, Wang et al. (2008) reported that average annual precipitation and runoff were 447 and $16 \mathrm{~mm}$ for forestlands, and 424 and 39 $\mathrm{mm}$ for non-forestlands, respectively. This example clearly demonstrated that most precipitation in Yellow River basin was consumed by ET, and in some cases, ET (e.g., ET from plantation forests in very dry environments) can exceed precipitation with a negative water balance (Wang et al., 2011). The research from Chen et al. (2011) indicated that at the scale of sloping plots, the highest ET in the more forested ecosystems normally caused a greater water yield reduction relative to lower ET in the grasslands and shrublands. The soil water replenishment by rainfall during rainy seasons was not sufficient to fully recharge the soil water storage in Loess Plateau, Yellow River basin.

McVicar et al. (2010) reviewed 13 studies of paired catchments in Yellow River, and found that streamflow mainly decreased with afforestation, which was consistent with the results from the Yangtze River. In spite of the same change direction, the sensitivity of streamflow to forest changes is different between two large basins. In Yellow River, ET was the dominant water consumption and consequently streamflow change due to forest change is relatively small in terms of absolute amount. However, change percentages of streamflow can be large. For example, Wang et al. (2011) evaluated the forest changes and streamflow in 57 basins in Loess Plateau of China, and found that reforestation caused a decrease of only $23 \mathrm{~mm}$, but this magnitude change represents a large difference in relative terms as it equates up to $58 \%$ of annual runoff from non-forestlands. Thus, streamflow in Yellow River is more sensitive to forest change than that in Yangtze River in terms of change in percentages. In contrast, low ET percentages of total precipitation and high water production potentials in the Upper Yangtze River basin suggest that streamflow to forest changes is more sensitive in terms of absolute term even though the change in percentages is relatively small. Understanding different hydrological responses in those two contrasted basins can improve the design of our forest management practices for better water management and protection.

Forest or land cover and climate change are interactively affecting watershed hydrology. However, their integrated effects are largely dependant on their individual strengths and directions. The effects can be offsetting or additive. The research by Zhang et al. (2012) showed that historic climatic variability and forest disturbance produced an offsetting effect on annual mean flow in the study watershed. However, in the future, the effects from continuous reforestation plantations and climate change will likely be shifted to be negatively additive (Fig. 4). With continuous reforestation programs, more coniferous plantations will be established, which lead to higher ET and less streamflow. On the other hand, future climate change effects (temperature increasing) 


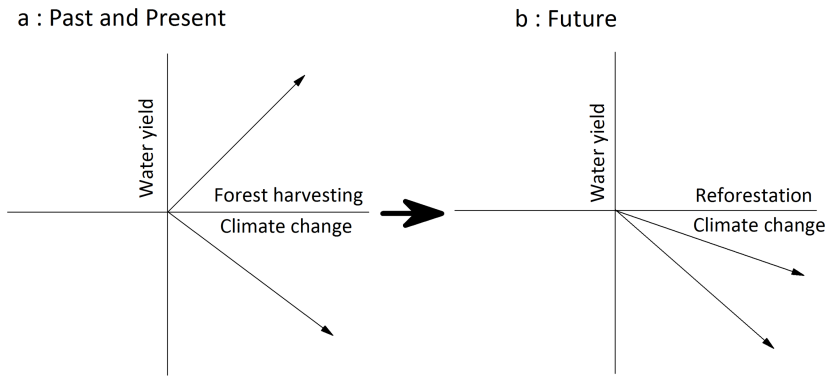

Fig. 4. A conceptual framework on how forest change and climate change interactively affect water yield - (a) past and present with forest harvesting and climate change; (b) future with reforestation and climate change).

will accelerate melting processes from glaciers and permanent snow, and eventually cause the decline or diminish of those important water sources in the long term. This decline has been reported in the Tibetan Plateau due to shrinking glaciers and permanent snow snowpacks (Shi and Li, 1994; Kang, 2005). Future temperature increases will also increase vegetation activities and ET, and consequently decrease water yield. Thus, both climate change and forest change will place double the pressure on future water resource supply in the watershed. Management and adaptation strategies must consider both land use and climate change and their interactive effects over time.

\section{Future research priorities or directions}

In spite of growing research on forest changes and hydrological processes at both forest stand and watershed scales in the Minjiang River watershed, they are still insufficient for a comprehensive review. Future research should consider the following priorities or directions in the watershed. First, more stand-level long-term experiments, such as the application of eddy covariance flux towers and isotopes, are needed to provide improved understanding of various ecohydrological processes or mechanisms in different types of forests as well as different structures or spatial configurations of the same forest types. This research will serve as an important base for understanding ecohydrological processes at larger spatial scales and heterogeneity of hydrologic processes of different ecosystem types. Second, sub-surface water or groundwater is rarely considered in studying forestwater relationships at both stand-level and watershed scales in the past. Given large complexities in geology and topography in the upper Minjiang River watershed, such research should be one of the most important priorities, and the results from this priority can provide critical information for understanding sources of water resources and their association with climate and land use or forest cover changes. Third, more landscape-level or large watershed scale studies should be conducted to gain better understanding of cumulative effects of forest cover changes and climate variability to hydrology. Those studies can also provide opportunities for examining ecohydrological processes and their relations with forest patterns and structures across spatial scales. Availability of long-term data (remote sensing, climate and hydrology) and advanced statistical techniques and simulation tools makes this priority feasible.

\section{Conclusions}

In the upper reach of Yangtze River basin, forest or land cover change has greatly affected hydrological processes at both the forest stand level and large watershed scales. At the forest stand level, forest change through harvesting or land conversion has affected canopy interception, ET, water use strategy of tree species, and consequently water yield. The general conclusion is that forest harvesting would initially increase water yield while regeneration or reforestation can eventually lead to increasing of ET and thus decreasing of water yield at the forest stand level. At the large watershed scale, land cover or forest change plays a similar role in streamflow as its role at the forest stand level, and its effects are as important as those from climate change in terms of magnitude. More importantly, our summary identifies that land cover or forest and climate change played an offsetting effect on streamflow in the past, but their effects will become negatively additive in the future with increasing re-growth of regeneration and future reforestation. Along with increasing temperature, there will be double the pressure on future water resources in the study watershed. Future research and watershed management strategies must consider this dynamic, interactive effect.

Acknowledgements. This review research was jointly funded by the Ministry of Finance (200804001 and 201104006), the Ministry of Science and Technology (2002CB111500; 2011CB403205, 2012BAD22B01), China's National Natural Science Foundation (No. 30590383) and Chinese Academy of Forestry Foundation (CAFYBB2008007).

Edited by: G. Sun

\section{References}

Bethlahmy, N.: More streamflow after a bark beetle epidemic, J. Hydrol., 23, 3-4, doi:10.1016/0022-1694(74)90001-8, 1974.

Buttle, J. M. and Metcalfe, R. A.: Boreal forest disturbance and streamflow response, northeastern Ontario, Can. J. Fish. Aquat. Sci., 57, 5-18, doi:10.1139/cjfas-57-S2-5, 2000.

Chang, Z., Bao, W., He, B., Yang, Y., and He, Q.: Interception and distribution effects of mixed artificial Pinus Tabulaef ormis and Pinus armandi forests on precipitation in the upper reaches of Minjiang River, J. Soil Water Conserv., 20, 37-40, 2006. 
Chen, J., Li, X., and Zhang, M.: Simulating the impacts of climate variation and land-cover changes on basin hydrology: A case study of the Suomo basin, Sci. China Ser. D, 48, 1501-1509, doi:10.1360/03yd0269, 2005.

Chen, L., Wang, J., Wei, W., Fu, B., and Wu, D.: Effects of landscape restoration on soil water storage and water use in the Loess Plateau Region, China, Forest Ecol. Manage., 259, 1291-1298, doi:10.1016/j.foreco.2009.10.025, 2011.

Chen, Z. and Ren, S.: Effect of Forest Hydrology in the Upstream Minjiang River (From Zhenjiangguan to Zipingpu), Sichuan Forest. Sci. Technol., 11, 27-34, 1990.

Cheng, G.: Forest Change: Hydrological Effects in the Upper Yangtze River Valley, Ambio, 28, 457-459, 1999.

Cheng, J.: Streamflow changes after clear-cut logging of a pine beetle-infested watershed in southern British Columbia, Canada, Water Resour. Res., 25, 449-456, doi:10.1029/WR025i003p00449, 1989.

Costa, M., Botta, A., and Cardille, J.: Effects of large-scale changes in land cover on the discharge of the Tocantins River, Southeastern Amazonia, J. Hydrol., 283, 206-217, doi:10.1016/S00221694(03)00267-1, 2003.

Cui, J., An, S., Wang, Z., Fang, C., Liu, Y., Yang, H., Xu, Z., and Liu, S.: Using deuterium excess to determine the sources of highaltitude precipitation: Implications in hydrological relations between sub-alpine forests and alpine meadows, J. Hydrol., 373, 24-33, doi:10.1016/j.jhydrol.2009.04.005, 2009.

Doerr, S. and Shakesby, R.: Forest fire impacts on catchment hydrology: A critical review, Forest Ecol. Manage., 234, S161, doi:10.1016/j.foreco.2006.08.212, 2006.

Eschner, A. R. and Satterlund, D. R.: Forest protection and streamflow from an Adirondack watershed, Water Resour. Res., 2, 765783, doi:10.1029/WR002i004p00765, 1966.

Fan, H.: A Study on 50 a Land Use and Cover Change of Watershed of Upper Minjiang River, J. Mount. Sci., 20, 64-69, doi:CNKI:SUN:SDYA.0.2002-01-010, 2002.

Fu, Y., Zhang, G., Li, F., and Liu, B.: Countermeasures for QinghaiTibet Plateau to Cope with Climate Change and Ecological Environment Safety, Agr. Sci. Tech., 11, 140-146, 2010.

He, C., Xue, J., Wu, Y., and Zhang, L.: Application of a revised Gash analytical model to simulate subalpine Quercus aquifolioides forest canopy interception in the upper reaches of Minjiang River, Acta Ecolog. Sin., 30, 1125-1132, 2010.

Hörmann, G., Branding, A., Clemen, T., Herbst, M., Hinrichs, A., and Thamm, F.: Calculation and simulation of wind controlled canopy interception of a beech forest in Northern German, Agr. Forest Meteorol., 79, 131-148, doi:10.1016/01681923(95)02275-9, 1996.

Huff, D., Hargrove, B., Tharp, M. L., and Graham, R.: Managing Forests for Water Yield: The Importance of Scale, J. Forest, 98, 15-19, 2000.

Jackson, R. B., Jobbágy, E. G., Avissar, R., Roy, S. B., Barrett, D. G., Cook, C. W., Farley, K. A., le Maitre, D. C., McCarl, B. A., and Murray, B. C.: Trading water for carbon with biological carbon sequestration, Science, 310, 1944-1947, doi:10.1126/science.1119282, 2005.

Johns, T. C., Carnell, R. E., Crossley, J. F., Gregory, J. M., Mitchell, J. F. B., Senior, C. A., Tett, S. F. B., and Wood, R. A.: The second Hadley Centre coupled ocean-atmosphere GCM: model description, spinup and validation, Clim. Dynam., 13, 103-134, doi:10.1007/s003820050155, 1997.

Kang, S.: Glaciers of Tibetan Plateau and global climate change, China Nat., 3, 10-11, 2005.

Li, K. Y., Coe, M. T., Ramankutty, N., and Jong, R. D.: Modeling the hydrological impact of land-use change, J. Hydrol., 337, 258268, doi:10.1016/j.jhydrol.2007.01.038, 2007.

Lin, Y. and Wei, X.: The impact of large-scale forest harvesting on hydrology in the Willow watershed of Central British Columbia, J. Hydrol., 359, 141-149, doi:10.1016/j.jhydrol.2008.06.023, 2008.

Liu, J., Li, S., Ouyang, Z., Tam, C., and Chen, X.: Ecological and socioeconomic effects of China's policies for ecosystem services, P. Natl. Acad. Sci. USA, 105, 9477-9482, doi:10.1073/pnas.0706436105, 2008.

Liu, S., Wen, Y., and Wang, B.: The function of hydrological ecology of forest ecosystems in China, China forestry Publisher, Beijing, China, 1996.

Liu, S., Sun, P., Wang, X., and Chen, L.: Hydrological functions of forest vegetation in upper reaches of the Yangze River, J. Nat. Resour., 16, 451-456, 2001.

Liu, X. and Hou, P.: Relationship Between the Climatic Warming Over the Qinghai-Tibet Plateau and its Surrounding Areas in Recent 30 Years and the Elevation, Plateau Meteorol., 17, 245-249, 1998.

Liu, Y., An, S., Deng, Z., Fan, N., Yang, H., Wang, Z., Zhi, Y., Zhou, C., and Liu, S.: Effects of vegetation patterns on yields of the surface and subsurface waters in the Heishui Alpine Valley in west China, Hydrol. Earth Syst. Sci. Discuss., 3, 1021-1043, doi:10.5194/hessd-3-1021-2006, 2006.

Liu, Y., Fan, N., An, S., Bai, X., Liu, F., Xu, Z., Wang, Z., and Liu, S.: Characteristics of water isotopes and hydrograph separation during the wet season in the Heishui River, China, J. Hydrol., 353, 314-321, doi:10.1016/j.jhydrol.2008.02.017, 2008a.

Liu, Y., An, S., Xu, Z., Fan, N., Cui, J., Wang, Z., Liu, S., Pan, J., and Lin, G.: Spatio-temporal variation of stable isotopes of river waters, water source identification and water security in the Heishui Valley (China) during the dry-season, Hydrogeol. J., 16, 311-319, doi:10.1007/s10040-007-0260-3, 2008b.

Lú, X. and Lú, X.: Climate Tendency Analysis of Warming and Drying in Grassland of Northeast Qinghai-Tibet Plateau of China, Grass. China, 24, 8-13, 2002.

Lű, Y., Liu, S., Sun, P., Liu, X., and Zhang, R.: Canopy interception of sub-alpine dark coniferous communities in western Sichuan, China, Chinese J. Appl. Ecol., 18, 2398-2405, 2007.

Ma, X.: Preliminary' study on hydrologic function of fir forest in Miyaluo region of Sichuan, Scientia Silvae Sin., 23, 253-264, 1987.

Ma, X.: Forest hydrology, China Forestry Publishing House, Beijing, China, 1993.

Matheussen, B., Kirschbaum, R. L., Goodman, I. A., O’Donnell, G. M., and Lettenmaier, D. P.: Effects of land cover change on streamflow in the interior Columbia River Basin (USA and Canada), Hydrol. Process., 14, 867-885, doi:10.1002/(SICI)1099-1085(20000415)14:5;867::AIDHYP975;3.0.CO;2-5, 2000.

McVicar, T., Niel, T., Li, L., Wen, Z., Yang, Q., Li, R., and Jiao, F.: Parsimoniously modelling perennial vegetation suitability and identifying priority areas to support China's re-vegetation program in the Loess Plateau: Matching model complexity 
to data availability, Forest Ecol. Manage., 259, 1277-1290, doi:10.1016/j.foreco.2009.05.002, 2010.

Milly, P. C. D. and Dunne, K. A.: Macroscale water fluxes: 2. Water and energy supply control of their interannual variability, Water Resour. Res., 38, 1206, doi:10.1029/2001WR000760, 2002.

Moore, R. and Wondzell, S.: Physical hydrology and the effects of forest harvesting in the Pacific Northwest: a review, J. Am. Water Reour. Assoc., 41, 763-784, doi:10.1111/j.17521688.2005.tb04463.x, 2005.

Richard, L.: Forest hydrology, Columbia University Press, NY, doi:10.1007/BF03160622, 1980 .

Ring, P. J. and Fisher, I. H.: The effects of changes in land use on runoff from large catchments in the Upper Macintyre Valley, NSW, Sydney, Australia, Institution of Engineers, Barton, Australia, ACT, 1985.

Robinson, M., Cognard-Plancq, A., Cosandey, C., David, J., Durand, P., Führer, H., Hall, R., Hendriques, M. O., Marc, V., McCarthy, R., McDonnell, M., Martin, C., Nisbet, T., O'Dea, P., Rodgers, M., and Zollner, A.: Studies of the impact of forests on peak flows and baseflows: a European perspective, Forest Ecol. Manage., 186, 85-97, doi:10.1016/S0378-1127(03)00238X, 2003 .

Scott, D. F. and Lesch, W.: Streamflow responses to afforestation with Eucalyptus grandis and Pinus patula and to felling in the Mokobulaan catchments, South Africa, J. Hydrol., 199, 3-4, doi:10.1016/S0022-1694(96)03336-7, 1997.

Shi, P., Wu, B., Cheng, G., and Luo, J.: Water retention capacity evaluation of main forest vegetation types in the upper Yangtze Basin, J. Nat. Resour., 19, 351-360, 2004.

Shi, Y. and Li, J.: New process on the glaciological and Quaternary glacier research in China since the 1980s, J. Glaciol. Geocryol., $16,1-12,1994$.

Siriwardena, L., Finlayson, B. L., and McMahon, T. A.: The impact of land use change on catchment hydrology in large catchments: The Comet River, Central Queensland, Australia, J. Hydrol., 326, 199-214, doi:10.1016/j.jhydrol.2005.10.030, 2006.

Song, Z.: Eco-hydrological effects of forests and decision-making for forestry development, Sci. Soil Water Conserv., 5, 101-107, 2007.

Sun, G., McNulty, S. G., Lu, J., Amatya, D. M., Liang, Y., and Kolka, R. K.: Regional annual water yield from forest lands and its response to potential deforestation across the southeastern United States, J. Hydrol., 308, 258-268, doi:10.1016/j.jhydrol.2004.11.021, 2005.

Sun, G., Zuo, C., Liu, S., Liu, M., McNulty, S. G., and Vose, J. M.: Watershed evapotranspiration increased due to changes in vegetation composition and structure under a subtropic climate, J. Am. Water Resour. Assoc., 44, 1164-1175, 2008.

Sun, P., Liu, S., Jiang, H., Lü, Y., Liu, J., Lin, Y., and Liu, X.: Hydrologic Effects of NDVI Time Series in a Context of Climatic Variability in an Upstream Catchment of the Minjiang River, J. Am. Water Resour. Assoc., 44, 1132-1143, doi:10.1111/j.17521688.2008.00256.x, 2008.

Tan, C., Liu, X., and Wang, N.: Climate Change Range of QinghaiTibet Plateau, Chin. Sci. Bull., 45, 98-106, 2000.

Thanapakpawin, P., Richey, J., Thomas, D., Rodda, S., Campbell, B., and Logsdon, M.: Effects of landuse change on the hydrologic regime of the Mae Chaem river basin, NW Thailand, J. Hydrol., 334, 215-230, doi:10.1016/j.jhydrol.2006.10.012, 2007.
Tuteja, N. K., Vaze, J., Teng, J., and Mutendeudzi, M.: Partitioning the effects of pine plantations and climate variability on runoff from a large catchment in southeastern Australia, Water Resour. Res., 43, W08415, doi:10.1029/2006WR005016, 2007.

VanShaar, J. R.: Effects of land-cover changes on the hydrological response of interior Columbia River basin forested catchments, Hydrol. Process., 16, 2499-2520, doi:10.1002/hyp.1017, 2002.

Wang, Y., Yu, P., Feger, K., Wei, X., Sun, G., Bonell, M., Xiong, W., Zhang, S., and Xu, L.: Annual runoff and evapotranspiration of forestlands and non-forestlands in selected basins of the Loess Plateau of China, Ecohydrology, 4, 277-287, doi:10.1002/eco.215, 2011.

Wei, X. and Zhang, M.: Quantifying streamflow change caused by forest disturbance at a large spatial scale: A single watershed study, Water Resour. Res., 46, W12525, doi:10.1029/2010WR009250, 2010.

Wilcox, B. P. and Huang, Y.: Woody plant encroachment paradox: Rivers rebound as degraded grasslands convert to woodlands, Geophys. Res. Lett., 37, L07402, doi:10.1029/2009GL041929, 2010.

Wilk, J., Andersson, L., and Plermkamon, V.: Hydrological impacts of forest conversion to agriculture in a large river basin in northeast Thailand, Hydrol. Process., 15, 2729-2748, doi:10.1002/hyp.229, 2001.

Xu, J., Yang, D., Yi, Y., Lei, Z., Chen, J., and Yang, W.: Spatial and temporal variation of runoff in the Yangtze River basin during the past 40 years, Quatern. Int., 186, 32-42, doi:10.1016/j.quaint.2007.10.014, 2008.

Xu, Q., Liu, S., Wan, X., Jiang, C., Song, X., and Wang, J.: Effects of rainfall on soil moisture and water movement in a subalpine dark coniferous forest in southwestern China, Hydrol. Process., doi:10.1002/hyp.8400, in press, 2011a.

Xu, Q., Li, H., Chen, J., Cheng, X., Liu, S., and An, S.: Water use patterns of three species in subalpine forest, Southwest China: the deuterium isotope approach, Ecohydology, 4, 236244, doi:10.1002/eco.179, 2011 b.

Yang, W., Wang, K., Seppo, K., and Xiao, L.: Wet Canopy Evaporation Rate of Three Stands in the Western Sichuan, J. Mount Sci., 1, 166-174, doi:10.1007/BF02919338, 2004.

Yang, Z. and Woo, M.: Streamflow characterisitcs of the Eastern Qinghai Plateau, J. Glaciol. Geocry., 12, 219-226, 1990.

Yu, X., Zhao, Y., Zhang, Z., and Cheng, G.: Characteristics of soil water infiltration in subalpine dark coniferous ecosystem of upper reaches of Yangtze River, Chin. J. Appl. Ecol., 14, 15-19, 2003.

Zhang, L., Jiang, H., Wei, X., Zhu, Q., Liu, S., Sun, P., and Liu, $\mathrm{J}$.: Evapotranspiration in the meso-scale forested watersheds in Minjiang valley, West China, J. Am. Water Resour. Assoc., 44, 1154-1163, doi:10.1111/j.1752-1688.2008.00245.x, 2008.

Zhang, M., Wei, X., Sun, P., and Liu, S.: The effect of forest harvesting and climatic variability on streamflow in a large watershed: the case study in the Upper Minjiang River of Yangtze River basin, J. Hydrol., 464-465, 1-11. doi:10.1016/j.jhydrol.2012.05.050, 2012.

Zhang, W., Li, M., Wu, Z., and Yang, B.: Features and evaluation of glacial landscape resources in Heishui County, Sichuan Province, J. Mount. Sci., 20, 461-465, 2002. 
Zhang, Y., Zhao, C., and Liu, S.: The Influence Factors of Subalpine Forest Restoration in Miyaluo, West Sichuan, Scientia Silvae Sin., 41, 189-193, 2005.

Zhang, Y., Liu, S., Wei, X., Liu, J., and Zhang, G.: Potential impact of afforestation on water yield in the subalpine region of southwestern china, J. Am. Water Resour. Assoc., 44, 1144-1153, doi:10.1111/j.1752-1688.2008.00239.x, 2008.

Zhang, Y., Liu, S., Luo, C., Zhang, G., and Ma, J.: Water holding capacity of ground covers and soils in different land uses and land covers in subalpine region of Western Sichuan, China, Acta. Ecolog. Sin., 29, 627-635, 2009.

Zhang, Y., Liu, S., and Gu, F.: The impact of forest vegetation change on water yield in subalphine region of southwestern China, Acta. Ecolog. Sin., 31, 7601-7608, 2011.
Zhao, F., Zhang, L., Xu, Z., and Scott, D. F.: Evaluation of methods for estimating the effects of vegetation change and climate variability on streamflow, Water Resour. Res., 46, W03505, doi:10.1029/2009WR007702, 2010.

Zhou, G. and Yan, J.: Theories and practice of compensation for ecological forests, China Meterological Press, Beijing, China, 2000.

Zhou, P., Luukkanen, O., Tokola, T., and Nieminen, J.: Vegetation Dynamics and Forest Landscape Restoration in the Upper Min River Watershed, Sichuan, China, Restor. Ecol., 16, 348-358, doi:10.1111/j.1526-100X.2007.00307.x, 2008. 